\title{
Utószó a Rendészettudományi szaklexikonhoz
}

\author{
Postscript to the Specialist Lexicon of Police Science
}

\begin{abstract}
Absztrakt
A szerző egy felkérésnek eleget téve, mint a Magyar Rendészettudomány Társaság elnöke, előszót írt a 2019-ben megjelent Rendészettudományi szaklexikonhoz. A mü megjelenése és tanulmányozása után úgy érezte, hogy újra tollat kell ragadnia, hogy kritikát mondjon, s fogalmazzon meg az általa vélt hiányosságok, illetve a követendő példák vonatkozásában.
\end{abstract}

Kulcsszavak: rendészettudományi szaklexikon, rendészet

\begin{abstract}
The author wrote on a summons, as president of the Hungarian Association of Police Science, a preface to the Specialist Lexicon of Police Science published in 2019. After the publication and after the survey of that he got the motivation to criticism and to formulation of opinion on meant incompleteness, resp. on examples to be followed.
\end{abstract}

Keywords: Specialist Lexicon of Police Science, policing

\section{Bevezetés}

A Rendészettudományi szaklexikon szerkesztői jó egy évvel ezelőtt felkértek, hogy mint a Magyar Rendészettudományi Társaság elnöke írjak előszót az akkor már befejezés előtt álló kötetükhöz. Tekintve, hogy a kötet létrejöttéhez vezető munkálatok legalább húsz évvel ezelőtt kezdődtek, ennek a felkérésnek nagy örömmel tettem eleget. Akkor is és most is öszinte szívvel vallom, e mü 
mérföldkő, mely sok jószándékú szakember közös erőfeszítéseként, hosszú évek munkája után született meg. Fontos lenyomata korunknak és még inkább a mögöttünk hagyott évtizedek tudományos teljesítményének. Így a megtisztelő felkérésnek eleget téve megírtam az előszót, amelyben ezt a nagy terjedelmü munkát palackpostának neveztem (Boda, 2019). Az alkotókban leltárkészítő szándékot véltem felfedezni, amivel a húszéves 21. század az elkövetkezendő évtizedek polgárai, rendészeti szakemberei és a rendészetet kutató utódok számára üzen. Mert ne feledjük, a lexikon a felvilágosodás találmánya, címzettje a müvelt polgár, aki a mindenséggel szeretné mérni magát, a szakember, aki szakmájának fundamentumait az elmélyült tudásban keresi, és a kutató, aki az elődök tapasztalataira támaszkodva juthat új felismerésekre. A leltár mindhárom befogadó közeg számára hasznos lehet.

Annak, hogy mégis újra tollat ragadtam az az oka, amit Churchill nagyon szemléletesen fejez ki: „ugródeszkaként és ne diványként” tekintsünk a múltunkra! Vagyis legyünk büszkék az elkészült nagy müre, tekintsünk rá úgy, hogy elkészült a földszint, de folyamatosan munkálkodni kell, hogy a mi nemzedékünk egy olyan épületet adjon át a következő generációnak, amitől kötelességüknek érzik majd, hogy tovább magasítsák. Ugyanis a lexikont tanulmányozva egyre határozottabban azt érzem, hogy ez a palackposta nem a 21. század, hanem a 19. század üzenete. A történetiség nem felróható, de az már igen, ha a nagy elődök gondolatairól nem jut eszünkbe semmi mindabból, ami az elmúlt több mint száz esztendőben a rendészetet jellemezte. Ez a feledékenység korrekcióra szorul. A tudomány nem kinyilatkoztatás, hanem igazságkeresés; az elmélet nem feladatszabás, hanem próbatétel, ütköző nézetek, érvek és cáfolatok labirintusa. Ettől a rendészettudomány sem kímélheti meg magát. A Rendészettudományi szaklexikon szerkesztôi jól érzékelhetően tartanak ettől a szellemi rendetlenségtől, s az óvatossággal egy fiatal tudományág jövőjét kockáztatják. Pedig lenne honnan tapasztalatokat gyüjteni az elméleti építkezéshez. A következőkben néhány példával kívánom alátámasztani ezt a diagnózist.

Idézem a lexikon meghatározását a bűnüldözési célú felderítésről: „,... az Alaptörvényben megjelenitett bünüldözési célok érdekében, a bünüldözési ágazati törvényekben megjelenitett feladatszabás alapján végrehajtott a magán- és családi élet, a magánlakás és levelezés tiszteletben tartásához és ehhez szorosan kapcsolódó információs önrendelkezéshez, az információáramlás szabadságához és a $\rightarrow$ személyes adatok védelméhez füzödö jogot is korlátozható, proaktív információszerzö tevékenység. $A \sim a \rightarrow$ rendörség és a $\rightarrow$ Nemzeti Adó- és Vámhivatal hatáskörébe utalt $\rightarrow$ büncselekmények felderitésére, megakadályozására, $a \rightarrow$ közbiztonság és az $\rightarrow$ államhatár rendjének védelmére, a $\rightarrow$ terrorizmus elleni küzdelem, a pénzmosás és a terrorizmus 
finanszirrozásának megelözésére és megakadályozására, belsö bünmegelözési, bünfelderitési célú ellenörzésre, valamint $a \rightarrow$ büncselekményböl eredö vagyon visszaszerzésére irányul.

$<$ crime detection $>$ " 1

Eltekintve most a fogalmazás szolgálati szabályzatokat idéző stílusától, az, amiről ebben a definícióban egyetlen szó sem esik, az éppen a tudomány - és bizony, a rendészettudomány - valódi feladata. A kincstári kifejezések mögött felsejlő igazi probléma a rendészeti és az igazságszolgáltatási tartalmak jogállami harmóniájának megteremtése. A lexikon minderről nem szól, annak ellenére, hogy a hazai szakirodalom bővelkedik gondolatokban. Lássunk az utóbbira egy mintát:

„A bünüldözés is integráns része a rendészeti igazgatásnak, a munkamegosztás rendjén azonban szervezetileg is elkülönül egymástól a rendet óvó és az azonnali beavatkozásra felesküdött közbiztonsági rendörség (la police bas), valamint a jogrend helyreállitásában segédkezö biztonsági rendörség" (la haute police)." Amit Concha segédkezésnek nevez, azt az újabb irodalom az igazságszolgáltatás, a büntető per előkészítésének mondja. További elválasztó ismérv, hogy ,, a bünüldözés nem a társadalmi rendet biztositja, hanem a büntetést" (Concha, 1905, 314.). Hallatlanul fontos megállapítás, azt is mondhatjuk, hogy a jogállam egyik axiómája. Ha ez az elv nem érvényesül, végzetesen összekeveredik a két hatalmi ág, a végrehajtó hatalom és a bíráskodás társadalmi rendeltetése. A rendőr büntetni akar, mert az igazság birtokosának érzi magát (szakmai szerepéből adódóan időnként csakugyan az), úgy gondolja, hogy nincs szükség a független bíróságra. A bíró viszont - amennyiben az igazságszolgáltatásnak olyan társadalomvédelmi funkciót tulajdonít, amelyre az valójában nem alkalmas - a társadalom védelmezőjeként a rendőr szerepébe helyezi magát, úgy vélve, hogy a közösség érdeke esetenként még az igazság megállapítását is mellőzhetővé teszi. Concha figyelmeztet erre a veszélyre, de jelzi azt is, hogy „, a jog uralma, amelyet végsö soron a bíróság tart fenn, adja az egyénnek valamint az államhatalomnak azt az érzést, amelyet biztonságnak nevezünk" (Concha, 1905, 314.). Fontos hangsúlyozni, hogy ebben az esetben nem a kriminológiából ismert szubjektív biztonságról van szó, hanem arról a biztonságról, amelyben az állam nyugodt lehet afelől, hogy az általa megalkotott büntetőtilalmaknak csakugyan érvényt fognak szerezni, az egyén pedig biztos lehet abban, hogy a bíróságok függetlensége az államhatalom önkényétől is képes lesz megvédelmezni őt (Finszter, 2018, 218-219.). Finszter Gézát nem csupán azért idéztem, mert példát szerettem volna nyújtani egy probléma

1 Rendészettudományi szaklexikon, 99. 
tudományos igényü megközelítésére, hanem azért is, mert a rendészettörténetben járatos lexikonszerkesztők megfontolhatnák, hogyan lehetséges meríteni a klasszikusokból akként, hogy abban nyomatékot kapjanak a jelennek és a jövőnek szóló tanulságok is.

Vegyünk a lexikonból egy másik címszót, a rendőrállam meghatározását:

„Rendörállam: a modern $\rightarrow$ rendészet kialakulása elötti idöszakra jellemzö helyzet, illetve állapot, amelyben az uralkodó gondoskodik az alattvalóiról, és a polgárok minden viszonyát szabályozza.

$<$ police state $>$ "2

Ez már nem csupán igénytelen fogalmazás, hanem morális probléma. Pedig van a rendőrállamnak szakmailag és erkölcsileg is értékelhető leírása, így például:

- „Rendörállamokban a szervezett eröszak nem áll társadalmi ellenörzés alatt.

- A kényszeritö eszközöket önkényesen és/vagy kizárólag az uralkodó elit céljait szolgálva alkalmazzák.

- A rendőri tevékenység a szabad belátás korlátlan érvényesülésén alapszik (ide értve a birói itélet nélküli fogva tartást és a fizikai eröszak széles körben és következmények nélküli alkalmazását vallomás kicsikarása érdekében) [...] A második világháború utáni fejlett országokban, azoknak is fejlett polgári demokráciáiban terjedt el a jogállami minőségü jogot és a politikai demokráciát egyesitö alkotmányos jogállam, ahol az államszervezet felépitésének és müködtetésének fontos elve a hatalommegosztás. Végeredményben mindezek - joguralom/jogállam, demokratikus politikai rendszer és hatalommegosztás együtt biztosithatják a rendörállam kialakulásának megakadályozását." (Szigeti-Szilvásy, 2015, 19.)

Nézzünk egy harmadik példát. Mit mond a lexikon a közbiztonságról?

„Közbiztonság: (1) alapvetöen olyan közállapot, amelyben az egyes személyek és közösségek élete, müködése és javai a jogellenes támadásoktól nincsenek veszélyeztetve. (2) A társadalmi együttélés jogilag és a rendvédelmi szervek által fizikailag is oltalmazott állapota. (3) Az $\rightarrow$ állampolgárok élet- és vagyonbiztonságát jogilag szabályozott valamilyen - bizonyos mértékben még elfogadható szintü - közállapot. (4) Az adott társadalom tagjai személy-és vagyonbiztonságának a vonatkozó szabályozás szerinti megvalósulásának $\rightarrow$ állam általi garantálása.

$<$ public safety $>$ "3

És hogyan szól minderről a tudomány? Az idézet ismét Finszter Gézától származik:

2 Rendészettudományi szaklexikon, 484.

3 Rendészettudományi szaklexikon, 342-343. 
„A közbiztonság, mint jogi tárgy, védendö értékek összessége, amelyet a demokratikus jogállamok államcélként határoznak meg. Az állam köteles olyan állami intézményeket müködtetni, amelyek társadalmi rendeltetése a közbiztonság oltalmazása. 1990-ben neves külföldi rendörségi szakértők világitották át a legnagyobb magyar rendészeti szervezetet, a rendörséget. Egyik elsö jelentésükben ekként írtak a közbiztonságról: A közbiztonság a nem anyagi jellegü infrastruktúrának az a része, ami ahhoz szükséges, hogy az egyének és közösségeik megvalósithassák a társadalom számára értékes céljaikat. ${ }^{4}$ A közbiztonság védelmezése beruházás-igényes feladat, amiként példának okáért az útépités is nagyon drága vállalkozás. De az idézett formulában van még egy felismerés: a közbiztonság csak akkor értelmes, ha támogatja a kockázatokat is hordozó, személyes bátorságot és autonómiát követelö, felelösséget is vállaló értékteremtő munkát. Az alkotó tevékenység egyéni és közösségi szabadságjogokat feltételez. Az a biztonság, amely az emberi jogok megsemmisitésével érhetö el, semmit nem ér, mert az ilyen állapot a társadalomnak a teremtó erejét pusztítja el." (Finszter, 2018, 486-487.)

A lexikonban olvashatunk a rendőri professzionizmusról:

„,Rendöri professzionalizmus: $a \rightarrow$ rendörség mindennapi müködésének, hatékonysági mutatói egyik fontos feltétele, amelynek következtében a rendörségi alkalmazott jól átlátható és megalapozott, részben különleges ismeretek (kompetenciák) birtokában, sajátos cselekvési formák keretében, mesteri módon végzi mindennapi alaptevékenységét, továbbá korszerü, hatékony szakmaiság, racionalitás és állandó megújulás jellemzi. A , a fegyelmezett szolgálatellátás, az etikus hivatásgyakorlás elengedhetetlen feltételei a fegyveres szervek és $a z \rightarrow$ állampolgárok súrlódásmentes együttmüködésének. A rendörségi szervezetben dolgozók professzionalizmusának szükségessége elöször az 1930-as években merült fel. August Vollmer (1876-1955), a 20. század elejének meghatározó kriminológiai szakembere és a Los Angeles-i rendörkapitányság vezetöje reformálta meg a képzést annak érdekében, hogy a rendörség magasabb színvonalon tudja végezni a munkáját... "5

Az csak helyeselhető, hogy a rendőri szakértelem értelmezése során külföldi példákkal is megismerkedünk. Nagyon hiányzik azonban a professzió körül kialakult hazai vitáknak legalább a felvillantása. Hogyan írt erről Szikinger István 1998-ban megjelent ,Rendörség a demokratikus jogállamban” címü monográfiájában:

4 „A hatékony és demokratikus magyar rendörségre vonatkozó javaslatok, Team Consult, PSC Warnsveld, 1991 (Kézirat)”

5 Rendészettudományi szaklexikon, 486-487. 
„A magyar rendvédelem története címü, a rendörképzésben tananyagként is használt összefoglaló munka szerint a két világháború között „, a rendvédelem profizmusát hangsúlyozó felfogások kerültek elötérbe”, ami a szerzö szerint nem a törvényesség háttérbe szoritását eredményezte, hanem csupán azt, hogy kiiktatták ,, a túlzottnak tartott biztositékokat” (Parádi, 1996, 130. o.). Mivel azonban [...] Magyarországnak sem írott alkotmánya, sem a rendészeti igazgatás felett törvényességi kontrollt gyakorló bíróságai nem voltak, igazán nehezen lehetett túlzott biztositékokat találni. Megitélés kérdése, hogy a polgári alkotmányosság alapértékeit tagadó - a zsidótörvényekig eljutó - rendszert kiszolgáló apparátust lehet-e professzionalistának tekinteni. Véleményem szerint nem, a polgári állam rendörségének és más rendvédelmi szervezeteinek profeszszionális jellegétöl elválaszthatatlan az alapjogok és más alkotmányos értékek tiszteletben tartása...« (Szikinger, 1998, 74.).

A szerkesztők és a szócikkek szerzői különös gonddal ügyeltek arra, hogy a szakmaiságot sehol ne oldják fel politikai megfontolások. Ez a törekvés azonban nem jelentheti azt, hogy megfeledkezzünk a humánum alapértékeiről, amelyeket a jogtól és annak rendészeti érvényre juttatásától minden demokratikus társadalom megkövetel. Az állam ,, akkor jogállam, ha a jogi értékekböl fakadóan konkrét humanitással teli, s a jognak léte és érvényesülése csak akkor a jog uralma, ha ez a jog az ember személyiségét és szabadságát biztositja éspedig itt és most. Vigyázzunk tehát - és ez a legfontosabb kötelességünk-ajog uralmának humánus tartalmára, a jog humánumára” (Kulcsár, 1990, 578.)

A következő példa a rendészettudomány forrásvidékére mutat. A rendőrségi reform a rendszerváltozás korszakának kihívása volt, amelynek elmaradása napjainkig érezteti hatását. A reform elméleti megalapozása a rendészettudomány önállósodásának egyik legfontosabb katalizátora, és egyben olyan adóság, amivel az új stúdium a mai napig tartozik. Ehhez képest a lexikon a következőket tartja fontosnak:

„Rendörségi reform: az új társadalmi szerepeknek megfelelö $\rightarrow$ rendörség kialakitására irányuló mozgalom és folyamat elnevezése. Az első az 1930-as években alakult, válaszként a nagy gazdasági világválság és a szesztilalom után kialakult $\rightarrow$ válsághelyzetre. A szesztilalom idején ugyanis a rendörség nagymértékben korrumpálódott és politikailag függö helyzetbe került.

A második $\sim a \rightarrow$ bünözés elleni $\rightarrow$ háború és a rendfenntartás közötti társadalmi szerepváltás idején, az 1960-as években kezdödött, és az 1970-es években bontakozott ki.

A harmadik az 1990-es években kezdödött, és mindmáig a community policing követelményeinek megfelelően alakul.

$<$ police reform $>$ "6

6 Rendészettudományi szaklexikon, 490. 
Már nem meglepö, ha ismét Finszter Gézához fordulok, aki a rendészet elméletét megalapozó monográfiájában részletezi a reform fogalmát és természetét: „Reformra akkor van szükség, amikor a társadalmi tevékenység valamennyi elemét egyaránt érintö fordulat következik be, amely a korábbi idöszak éles kritikáját jelenti, a múlttal való szakitást tüzi zászlajára, az új szervezeti, müködési és jogi formák a korábbiak tagadásából nőnek ki, és a reform a társadalom valamennyi müködö komplexumát átalakitja. A reform soha nem lehet parciális, az ilyen változtatás csak holisztikus (a rendszer valamennyi alrendszerét érintö) szemlélettel vezényelhetöle. A korszerüsités a technikai fejlödéssel egyre gyakrabban és sürübben kerül napirendre, a modernizációhoz sem kellenek nagy társadalmi változások, a reformok ideje viszont csak nagyon ritkán, kivételes történelmi pillanatokban jöhet el. Ebböl viszont az is adódik, hogy az ilyen ritka alkalmakat le lehet késni, és el lehet szalasztani."

Nézzük, hogyan folytatódik az előbb idézett gondolatmenet:

„A reform akkor elkerülhetetlen, ha a rendészet tehetetlen a bünözéssel szemben, ha visszaél a rábizott hatalommal és, ha képtelen vonzó életpályát biztositani azoknak, akik ezt a szakmát választják. Olyan válság ritkán adódik, amikor valamennyi müködési zavar egy idöben van jelen, de a reform már akkor is indokolt, ha ezek közül akár egy is tartósnak bizonyul. Sokan úgy vélték, hogy a rendszerváltás volt az a ,kegyelmi pillanat”, amikor a minöségi megújulásnak a legjobbak voltak a feltételei. Ez a várakozás nem volt megalapozott. Ellenkezőleg, éppen a rendészetnek a tekintélyelvü hatalomgyakorlás időszakából örökölt szervezete és müködési filozófiája kapott kegyelmet. Végletes centralizáció, militarista müködési elvek, a civil társadalomtól való elkülönültség, egyoldalúan repressziv szakmai filozófia, az eröszak monopóliumának minden áron való megtartása, a szakma alacsony erkölcsi és anyagi rangja. A kialakult helyzet magyarázatra szorul, mert ami a diktatúrában természetes, az a demokratikus viszonyok között elfogadhatatlan. Alkotmányos rendszerekben a rendörség átalakitása közügy, megvalósitásához társadalmi igény, kormányzati elhatározás és szakmai meggyözödés szükséges. A közvélemény akkor követel reformot, ha elégedetlen a közbiztonsággal, de nem türi a hatósági önkényt sem. Az öntudatos polgár számára a szabadság és a biztonság egymást kiegészitö értékek, egyik sem törekedhet kizárólagosságra a másik rovására. Az elmúlt években ez a harmónia még nem jött létre." (Finszter, 2003, 227-228.)

Kemény kritika, akár vitatható is, de amit a lexikon szerzői tettek - a hallgatás - az teljességgel elfogadhatatlan.

A példákat tudnám folytatni, de nem teszem, föleg azért, mert forrásként továbbra is Finszter Géza munkásságából kellene merítenem, ami ellen ő tiltakozna 
a leghevesebben. A tudomány nem lehet sem silány, sem gyáva. Silány akkor, ha felkészületlen küldetésére, gyáva akkor, ha egyetlen törekvése a hierarchiának való megfelelés. A Rendészettudományi szaklexikon számos szócikke azt igazolja, hogy a szerzők képesek a tudományosság képviseletére és az igényes szerkesztésre. Példaadónak tartom - egyebek mellett - a természettudományos háttérrel megfogalmazott definíciókat. Annál sajnálatosabb, hogy éppen a rendészettudomány legjellemzőbb terminológiái nélkülözik ezt a mívességet. Az örvendetesen fejlődő hazai rendészettudomány igényli a fogalmak lehetőség szerinti egységes értelmezését, a kapcsolódó kutatások és a szélesebb közönség számára pedig szükséges az elért eredmények tömör meghatározások formájában megvalósuló átadása. A tartalom azonban sajnos nem teljes mértékben szolgálja ezen célok megvalósítását. A szócikkek többsége megfelelö, ám vannak olyan vitatható tételek, amelyek miatt a munka átdolgozása feltétlenül szükséges. Mindenekelőtt kifogásolható, hogy a címben megjelölt tudományterületen túlmutató definíciók is megjelennek a kötetben. Ez persze bizonyos mértékig szükségszerü. Mivel azonban mégiscsak egy közigazgatási tevékenységhez kapcsolódó fogalomrendszerről van szó, ezért egyenesen félrevezetőnek tartom az olyan címszavak beiktatását, mint például a „harcparancs”, ráadásul a rendészettel való kapcsolatot illetően bármilyen magyarázat nélkül. Más esetekben a meghatározás nem teljesen pontos. A „rendőr jogai” címszó meglehetősen esetleges válogatás alapján sorol fel néhány dolgot (például gyógykezeltetés, nyugdíj, temetkezési költség) anélkül, hogy egyáltalában jelezné például az intézkedési felhatalmazásokat vagy akár a rendőrre vonatkozó alapjogi korlátozásokat. Van olyan címszó is, ami véleményem szerint helytelen meghatározást tartalmaz. Az ,ítélet” például - ellentétben a lexikonnal - polgári ügy érdemi befejezését is jelentheti, másrészt jogorvoslati eljárásban is születhet, ami azt jelenti, hogy önálló fellebbezéssel - szintén a leírással ellenkezően - nem támadható.

Nyilvánvaló, hogy minden ilyen munkával kapcsolatban megfogalmazhatók belekívánások, vagyis teljesen zárt rendszert még egy jó lexikon sem képezhet. Hangsúlyozni kell, hogy tudományos adattárról van szó, ezért nem csupán a gyakorlatban, hanem a kutatások során felmerült, esetleg más országokban elterjedt fontosabb fogalmakról is tájékozódhatna az olvasó.

Néhány javasolt példa:

Brutalitás: az erőszak szükségtelen és/vagy aránytalan alkalmazása. Diszkrimináció: alkotmányosan nem indokolható hátrányos megkülönböztetés. Intézményes rasszizmus: az Egyesült Királyságban elfogadottan létező szervezeti és müködési torzulás, ahol a rendészeti szervek tagjainak gondolkodásától függetlenül is olyan mechanizmusok vannak jelen, amelyek szükségszerüen 
diszkriminatív megnyilvánulásokhoz vezetnek. Rendészeti generálklauzula: általános felhatalmazás olyan rendészeti beavatkozásokra, amelyek mögött nem áll tételes jogi felhatalmazás, de nem ütköznek a jog által feltétlenül érvényesíteni kívánt tilalmakba. Szelekció: a rendészeti szervek döntése az eljárásra vonatkozó kezdeményezések elfogadásáról, illetőleg elutasításáról olyan esetekben is, amikor a törvény helyes értelmezése ezt nem engedné meg. A szaklexikon feladata a tudományos nézetek bemutatása, a viták felvillantása. A ,palackpostában” erre is van követendö jó gyakorlat. A ,Rendészetfogalmak története” című szócikk példának okáért kimagasló igényességgel íródott. Igazolásként most csupán annak záró sorait idézem:

„8. Magyary megközelitése, rendészeten „, a közrendnek az egyesek által való megzavarása elleni védekezést értendö. $A \rightarrow$ rendészet a közigazgatásnak egyik ága, amelynek hatásköre $a \rightarrow$ közigazgatás minden más ágába belenyúlik, ezért tartozik az általános igazgatáshoz, de célja határozottan körül van irva: az általános nyugalom, biztonság és a rend biztositása. A rendészet nem pozitiv, hanem védö, elháritó tevékenység. Ebben is különbözik a szakirányú közigazgatástól, amelynek pozitív feladatai vannak." (Magyary, 1942) 9. Szamel szerint $a \rightarrow$ rendészet úgy határozható meg, mint ,olyan állami tevékenység, amely $a \rightarrow$ közrend megzavarásának megelözésére, a közvetlen zavaró magatartás megakadályozására és a megzavart rend helyreállitására irányul". (Szamel,

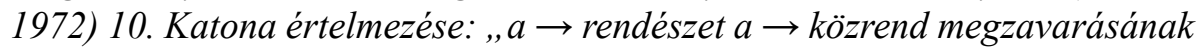
megelözésére, a közvetlenül zavaró magatartások, események, veszélyek megakadályozására, elháritására, a megzavart $\rightarrow$ rend helyreállitására irányuló tevékenység." (Katona, 2004) 11. Sallai féle meghatározásban a $\rightarrow$ rendészet „, az állam belügyi igazgatásának $a \rightarrow$ közrend és $a \rightarrow k$ közbiztonság fenntartására irányuló kényszeritö hatalommal rendelkezö tevékenysége". (Sallai, 2015) $<$ the concept of policing/law enforcement historicity $>$ " 7

Ilyen szerkesztési filozófia mellett az sem baj, ha egy-egy ismertetés akár több oldalt is elfoglal a lexikonban. Vegyünk ehhez egy további példát, ahol a bővebb terjedelem a színvonalat emelhette volna: ,, Statisztikai szemlélet: a rendöri munka értékelése a bünügyi statisztikai adatok, felderitési mutatók tükrében. Nem számol a $\rightarrow$ szubjektiv biztonságérzettel, látenciával. $A \rightarrow$ bünözés sajátosságaival és a felderitési mutatókkal kapcsolatosan statisztikai adatok 1894-töl jelentek meg nyomtatott formában az évente kiadott fökapitányi jelentésekben. $<$ statistical approach > "8

7 Rendészettudományi szaklexikon, 462.

8 Rendészettudományi szaklexikon, 507. 
A statisztikai szemlélet ennél jóval összetettebb jelenség. Alapvető oka a hierarchia igénye, ami a statisztikai adatokban fedezte fel azt az eszközt, amivel nagyon kevés vezető megfellebbezhetetlen ítéletet mondhat nagyon sok ember munkája felett. ,, A centralizált katonai elvek szerint müködö rendészet viszont azt igényli, hogy az első számú vezetők rövid idő alatt sok beosztott munkáját legyenek képesek egyszerü méröszámok segitségével minösiteni és összehasonlitani. Ez a módszer nem a munka minöségének a biztositásához, hanem az elöljárói hatalom növeléséhez és a beosztotti kiszolgáltatottság fokozásához szükséges." (Finszter, 2003, 225.) A szinte megváltoztathatatlannak tűnő statisztikai szemlélet következménye a szelektív munkamódszer kialakulása, ami a rendészet eredeti társadalmi rendeltetésével kerülhet ellentmondásba. Egyebek mellett a látenciakutatások mutattak rá a bünüldöző hatóságok ,,különféle szervezeti és müködési problémáira, így például a szelekciós munkamódszerre" (Korinek, 2010, 585-586.). Ennek rövid lényege, hogy a teljesítménykényszer miatt a nyomozó hatóságok a felderítési mutatót úgy befolyásolják, hogy a nagy kapacitásokat lekötő vagy eleve reménytelen ügyeket különféle trükkökkel nem engedik be a rendszerbe, nem regisztrálják azokat (Korinek, 1988, 44.).

Kritikai észrevételeim nem kérdőjelezik meg az elvégzett munka értékeit, ellenkezőleg, szándékom az, hogy a rendészeti enciklopédisták csapatát arra biztassam, legyenek büszkék elért eredményeikre, de ne feledkezzenek meg teljesítményük kontrolljáról sem. Utóbbi esetben küldetésük - különösen akkor, ha tervezik a javított kiadást is - megkerülhetetlen marad a rendészettudomány fejlesztésében.

\section{Tisztelt Olvasó!}

Szeretném még a látszatát is elkerülni, hogy a fenti gondolatokat bárki is hibajegyzéknek tekintse. Az a dicséretes vállalkozás, hogy százegynéhány szerző, szerkesztő és föszerkesztő hónapokig vagy évekig dolgozott természetesen nagyra értékelendő. De nincs sem befejezett, sem tökéletes alkotás. Jó lenne, ha ez a szerkesztőgárda nem széledne szét, sőt helyeselni tudnám, ha az internetes változatban az egyes címszavak után a szerzők nevüket adnák az adott megfogalmazáshoz - legalább monogramszerüen -, így ki-ki tudná, hogy ha jobbító ötlete van, kit keressen meg és vitassa meg vele egy-egy újonnan megjelent tudományos eredmény bekerülésének lehetőségét. Tehát a munka nem fejeződött be, hanem igazából csak most kezdődött el! 


\section{Felhasznált irodalom}

Boda J. (szerk.) (2019): Rendészettudományi szaklexikon. Dialóg Campus Finszter G. (2003): A rendészet elmélete. KJK-Kerszöv

Finszter G. (2018): Rendészettan. Dialóg Campus

Korinek L. (1988): A rejtett bünözés. Közgazdasági és Jogi Könyvkiadó

Korinek L. (2010): Kriminológia I. Magyar Közlöny Lap- és Könyvkiadó

Kulcsár K. (1990): Lehet-e demokrácia Magyarországon? Magyar Jog, 6-7, 578-588.

Szigeti P., Szilvásy Gy. P. (2015): Rendészet és emberi jogok. Rejtjel Kiadó

Szikinger I. (1998): Rendőrség a demokratikus jogállamban. SÍK Kiadó 